NIJOLE் BATARLIENÉ, Ph.D. ${ }^{1}$

(Corresponding author)

E-mail: nijole.batarliene@vgtu.lt

RAIMONDAS ŠAKALYS, Ph.D. student ${ }^{1}$

E-mail: raimondas.sakalys@vgtu.lt

${ }^{1}$ Department of Logistics and Transport Management

Faculty of Transport Engineering

Vilnius Gediminas Technical University

Plytines str. 27, LT-10105 Vilnius, Lithuania
Traffic Policy

Original Scientific Paper

Submitted: 23 July 2019

Accepted: 19 Feb. 2020

\title{
CRITERIA IMPACTING SYNCHRONIZATION OF TRANSPORT FLOWS ALONG INTERNATIONAL TRANSPORT CORRIDOR
}

\begin{abstract}
The main goal of this paper is to determine the main technical and technological criteria impacting the effectiveness of the synchronization of transport flows in the East-West Transport Corridor (EWTC) in the southern part of the Baltic Sea Region (BSR) corridor using a specific questionnaire. The results were processed using the Kendall rating correlation method, and the compatibility of the expert selection was analysed using a match factor. Following Kendall's concordance coefficient and consistency ratio values, the expert opinions were reconciled. In the course of the research using the Average Rank Transformation into Weights (ARTIW) method, the normalized subjective weights of the main technical and technological impacting synchronization of transport flows were determined. The outcomes of the research presented in the paper have shown that the main technical criteria impacting synchronization are: railway infrastructure and road transport infrastructure at the terminals. The most important technological interaction criteria are accessibility of seaports and accessibility of railway distribution stations. In the following stages of research, the main criteria of the above two factors should be used to create models and facilitate synchronization with the purpose of building an interconnected transport system spanning all modes of transport.
\end{abstract}

\section{KEY WORDS}

synchronization; technical interoperability; technological interaction; intermodal terminal; transport corridor;

\section{INTRODUCTION}

Good transport connections and effective logistic services are a pre-requisite for the competitive Baltic Sea Region. Maritime and hinterland terminals enable the transhipment of load units between various modes of transport and play a significant role in intermodal transport. The interaction between road transport sector as well as the sea and other modes of transport is a very important factor in developing the transport corridors.

The poorly developed network and low levels of interconnectivity between the sea and land terminals along the East-West transport corridors in the BSR have negative effects and are a major obstacle in increasing the international competitiveness of this transport corridor. Thus, the greatest priority is to be given to synchronising activities of intermodal transport terminals. To ensure the efficiency of the carriage process within TEN-T corridors and its connections with the third countries, greater interoperability of the existing infrastructure is necessary. Additionally, it is imperative to coordinate the managers' and operators' actions, as well as to maintain the technological integration of the sea and land Terminal Operating System (TOS).

A comprehensive literature review was performed to obtain knowledge on how the subject of synchromodality has been developed in the academic literature. The synchromodality is flexible $[1,2]$ and a novel transport concept called "synchromodality" has been proposed recently to green freight transport by fostering a modal shift towards environmentally friendly modes [3, 4] of transport such as water (barge or short sea), rail and/or road can be used [5] for container transportation $[4,6]$.

The new knowledge gained from this review served as the basis for further research. Defares [7], Behdani and others [1] presented synchromodality definitions, and the concepts are closest to the opinion of the authors of the paper. It could be stated that, according to these authors, the synchromodal 
transport system includes both transport operations and transport infrastructure (e.g. inland terminals) resources. The synchronization is the most difficult task for transit planners and schedulers [8]. This task is sometimes accomplished intuitively in practice by simplifying the problem in favour of coordination in a few key points in the network. However, a networkwide synchronization is a complex task by nature $[9,10]$.

The purpose and objective of the research are to determine the main technical and technological criteria impacting synchronization of transport flows along international transport corridor aiming at more effective usage capacities of transport hubs.

\section{BASIC HYPOTHESIS}

Rodrigue identified the necessity to synchronise the activities among intermodal transport terminals by linking transport activities with the globalisation challenges. Globalisation underlines higher levels of integration between production and distribution systems $[11,12]$.

The development of transport infrastructure, as well as different modes of transport, should be synchronised. It is worth noting that Rodrigue [11, 12] suggests cooperating to meet the challenges of globalisation, while Wilmsmeier [13] highlights the importance of interaction between seaport terminals located in international transport corridors and landbased intermodal terminals. They mainly link the integration of land-based intermodal transport with the seaports located in the very same corridor. Limbourg and Jourquin [14] draw particular attention to the importance of container terminal locations in the European transport network. By employing modern modelling instruments, the authors have justified the statement that in order for intermodal transport to be competitive, the distance should be longer than $343 \mathrm{~km}$. The authors have also presented the principles of the Hub-and-Spoke network design.

Networkwide synchronization is a complex task by nature. Several authors $[1,15,16]$ argue that cost, quality and sustainability targets are the key to achieving synchromodality; others [17-20] say that service quality is the most important criterion. Also, the sufficiency of infrastructure, such as congestions, bottlenecks, obstructions, have a major impact on the synchromodal transport $[18,21]$.

Paper [9] was published to address the problems of synchronization transport by addressing a number of key factors, but very briefly in terms of technical and technological factors. Therefore, the authors of this paper have put forward the following basic hypothesis: the synchronization of intermodal transport activities in international transport corridors depends on the technical characteristics of the terminals and technological interoperability. These factors have a significant impact on the transport flows synchronization.

Comprehensive literature [19, 20, 22-24] analysis made it possible to identify the main technical and technological criteria impacting synchromodality. These criteria are presented in Table 1.

$\mathrm{A}$ and $\mathrm{B}$ groups of criteria characterise the technical and technological terminal capacities, as well as the possibilities for the use of interoperability of the transport modes. The larger the terminals, the more developed is their infrastructure, technical equipment and specialisation, the more attractive they are for the use of multimodal transport in the international transport corridors.

Table 1 - Criteria influencing synchromodality of transport activity

\begin{tabular}{|c|c|c|}
\hline Titles of performance factor groups & Key factors criteria & References \\
\hline A. Technical qualities of terminals & $\begin{array}{l}\text { Railway infrastructure } \\
\text { Road transport infrastructure } \\
\text { Area of cargo storage } \\
\text { Technical equipment } \\
\text { Loading equipment }\end{array}$ & {$[22,23]$} \\
\hline B. Technological interaction & $\begin{array}{l}\text { Seaports accessibility } \\
\text { Railway distribution stations accessibility } \\
\text { Airports accessibility } \\
\text { Logistics centres accessibility } \\
\text { Operational interaction of intermodal transport } \\
\text { Roads accessibility } \\
\text { Railway accessibility } \\
\text { Inland waterways accessibility }\end{array}$ & {$[19,20,24]$} \\
\hline
\end{tabular}




\section{RESEARCH RESULTS}

\subsection{Methodology significance of criteria}

To rank the main criteria (presented in Table 1) their importance in the development of transport synchronization is necessary. The experts from Germany, Denmark, Sweden, Belarus, Ukraine and Lithuania conducted a survey by using a questionnaire (from January to April 2017). The responses were received from 14 experts and this was done in the framework of TENTacle (2019) project of the BSR INTERREG (2019) programme [25]. One of the aims of this project was to investigate the prospects of further development of transport networks, as well as the possibilities for a better convergence of transport planning, management and implementation of the integrity of transport patterns linking the EU BSR and the EU Eastern Partnership Countries [9].

The main purpose of the questionnaire was to assess (rank) the most important criteria of technical and technological criteria groups impacting synchronization of transport performance following the significance criteria.

All criteria of group A given in the questionnaire, which indicate the main technical characteristics of the terminals, were divided into five groups:

A1-Railway infrastructure. This factor is expressed in terms of the number (units) and the length [m] of railway trains at intermodal terminals.

A2 - Road transport infrastructure. This factor is expressed in terms of production area $\left[\mathrm{m}^{2}\right]$ of road transport infrastructure in a terminal (the area designed for vehicle parking near terminal entrance and/or area for road transport servicing at the terminal).

A3 - Area of cargo storage. Expressed in terms of the total storage volume $\left[\mathrm{m}^{2}\right]$ of intermodal units (TEU and ro-ro cargo).

A4 - Technical equipment expressed by the number of equipment to service intermodal cargo as refrigerated cargo containers, equipment to eliminate accidents of hazardous cargo, and area for container servicing (repairing).

A5 - Loading equipment. This factor is expressed in terms of the number of ITU maintenance equipment (units) for servicing intermodal transport units (refrigeration container handling equipment, equipment for the collection of hazardous cargo emergency consequences) and the production area (space of containers for partial repairs) $\left[\mathrm{m}^{2}\right]$.
Criteria of technological interaction (group B), which characterise the interoperability of transport modes are as follows:

B1 - Seaports accessibility, expressed in km.

B2 - Railway distribution stations accessibility, expressed in $\mathrm{km}$.

B3 - Airports accessibility, expressed in km.

B4 - Logistics centres accessibility, expressed in $\mathrm{km}$.

B5 - Operational interaction of intermodal transport loading carried out in order according to prior enquiries, expressed as percentage per month.

B6 - Roads accessibility, expressed in $\mathrm{km}$.

B7 - Railway accessibility, expressed in km.

B8 - Inland waterways accessibility, expressed in $\mathrm{km}$.

Each group in the questionnaire was distributed based on the significances of smaller criteria. All expert assessments were ranked.

According to the answers provided, the distribution and agreement of opinions can be estimated. The Kendall's concordance coefficient was estimated to serve this purpose [26]. The values in the concordance coefficient $(W)$ are in the range from 0 to 1. The higher the value obtained $(W)$, the less do the opinions differ regarding the question under analysis. The higher the $W$, the stronger the correlation of the variables. When all of the ranks coincide, then $W=1$.

Kendall's concordance coefficient is based on the sum of the ranks assigned by $n$ experts to each $j$-th criterion $R_{j}$ :

$R_{j}=\sum_{i=1}^{n} R_{i j}(j=1,2, \ldots, m)$

More exactly, it is based on sum $S$ of the squared deviations $R_{j}$ (the variance analogue) from the mean rank $\bar{R}$ :

$S=\sum_{j=1}^{m}\left(R_{j}-\bar{R}\right)^{2}$

The average criterion rank $\bar{R}$ is obtained by dividing the sum of ranks, assigned to the criterion by the experts, by the number of the criteria, $m$ :

$\bar{R}=\frac{\sum_{j=1}^{m} R_{i j}}{m}=\frac{\sum_{i=1}^{n} \sum_{j=1}^{m} R_{i j}}{m}$

where:

$R_{i j}$-rank assigned by $i$-th expert to $j$-th

criterion;

$n$-number of experts $(i=1,2, \ldots, n)$;

$m$-number of the criteria $(j=1,2, \ldots, m)$. 
If $S$ is a real sum of the square value calculated by Equation 2, the concordance coefficient $W$ is described (when there are no related ranks) by the ratio of the calculated $S$ value:

$W=\frac{12 \cdot S}{n^{s} \cdot\left(m^{3}-m\right)}$

When the estimates of the experts are in agreement, the value of the concordance coefficient $W$ is about one, but if these estimates differ to a great extent, the value of $W$ is about zero.

The sum of the squared deviations of ranks $R_{i j}$ of each criterion from the mean rank can be calculated as follows:

$S=\sum_{j=1}^{m}\left[\sum_{i=1}^{n} R_{i j}-\frac{1}{2} n \cdot(m+1)\right]^{2}$

where:

$m$-number of the criteria $(j=1,2, \ldots, m)$;

$n$-number of experts $(i=1,2, \ldots, n)$.

The value of the random number $S$ is calculated by adding the squared values given to all the criteria, which are enclosed in square brackets (Equation 5).

The concordance coefficient $W$ can be used in practice if its limiting value, showing the condition when expert estimates may be considered consistent, is determined.

Kendall and Gibbons [27] proved that when the number of the criteria is $m>7$ the significance of the concordance coefficient $W$ can be determined by using the Pearson's criteria (chi-squared test).

The random value is distributed according to $\chi^{2}$ :

$\chi^{2}=n \cdot(m-1) \cdot W=\frac{12 \cdot S}{n \cdot m \cdot(m+1)}$

with the degree of freedom $v=m-1$. Based on the selected confidence level $\alpha$ (which is assumed to be 0.05 or 0.01 ), the critical value $\chi_{v, \alpha}^{2}$ is found from the table of $\chi^{2}$ distribution with the degree of freedom $v=m-1$. If the value of $\chi^{2}$ calculated by Equation 6 is larger than $\chi_{v, \alpha}^{2}$, it shows that the experts' estimates are consistent.

The smallest value of the concordance coefficient $W_{\min }$ can be estimated by applying Equation 7:

$W_{\min }=\frac{\chi_{v, \alpha}^{2}}{n \cdot(m-1)}$

where:

$n$-expert opinions;

$m$-number of comparative criteria that indicates the quality of an object under analysis with the selected levels of significance $\alpha$ and degree of freedom $v=m-1$. Having calculated this value, it is thus not possible to assert that the expert opinions are in agreement; $\chi_{v, \alpha}^{2}$-critical Pearson's statistics when the degree of freedom and significant level are taken [28].

To assess the application possibilities of transport interoperability and associated efficiency in terminals, the experts were asked to evaluate the criteria impacting the application possibilities and attractiveness of intermodal terminals based on their technical and technological capabilities in international transport corridors.

When the quality of an object is assessed and allows it to be described by a single value and compared with the quality of other similar objects, the normalized criterion weight $\omega_{j}$ should be used. The significances (weight) of the criteria can be defined by ARTIW method [29] by which the relative importance of A and B criteria (Tables 3 and 5) is defined. For that, Equation 8 is applied:

$\omega_{j}=\frac{(m+1)-\bar{R}_{j}}{\sum_{j=1}^{m} \bar{R}_{j}}$

where:

$m$-the number of criteria showing importance of synchronization;

$\bar{R}_{j}$-average rank of $j$-th criterion calculated according to Equation 9:

$\bar{R}_{j}=\frac{\sum_{i=1}^{n} R_{i j}}{n}(j=1,2, \ldots, m)$

where

$R_{i j}$-the rank of the criteria granted by the experts; $n$-number of experts.

ARTIW method was first presented in 2011 by the author Sivilevičius [29]. The significances (weights) of the criteria describing the quality of an object are determined by experts, who normalize them (i.e. equate their sum to one) and use the method of average rank transformation into weight.

\subsection{Results and discussion}

Research data were processed by Kendall's concordance coefficient method and ARTIW method.

The ranks of the importance of each criteria of group A - Technical qualities of terminals, which were assigned by the experts, were used calculating the average ranks $\bar{R} j$, concordance coefficient $W$, Pearson's criteria (chi-squared test) $\chi^{2}$ and the normalized criterion weight $\omega_{j}$. All calculations were made according to the Equations given above. 
The average of each criterion ranks was calculated as follows:

A1 average rank $\bar{R}=\frac{\sum_{i=1}^{n} R_{i j}}{n}=\frac{31}{14}=2.21$; etc.

A2 average rank $\bar{R}=\frac{\sum_{i=1}^{n} R_{i j}}{n}=\frac{34}{14}=2.243$; etc.

It indicated the importance of indicators expressed in priorities. The sum of A group criteria ranks is 15 .

In the next step, the difference between the sum of the grades and the constant is calculated for each criterion, and the results are listed in the penultimate row of Table 2.

$$
\begin{aligned}
& \sum_{i=1}^{n} R_{i j}-\frac{1}{2} n \cdot(m+1)=31-\frac{14 \cdot(5+1)}{2}= \\
& =31-42=-11 ; \text { etc }
\end{aligned}
$$

The sum of the differences between all five factors is 0 . According to Equation 13 the sum of squared deviations is calculated:

$$
\left[\sum_{i=1}^{n} R_{i j}-\frac{1}{2} n \cdot(m+1)\right]^{2}=[31-42]^{2}=[-11]^{2}=121 ; \text { etc. }
$$

The total sum of the square deviations $S$ is 396 . The data of the calculated index difference squares of each criterion of group A is indicated in Table 2.

In order to be sure that the expert views are not contradictive, coefficient of concordance $W$ was calculated:

$$
\begin{aligned}
& W=\frac{12 \cdot S}{n^{2} \cdot\left(m^{3}-m\right)}=\frac{12 \cdot S}{14^{2} \cdot\left(5^{3}-5\right)}=\frac{12 \cdot 396}{196 \cdot 120}= \\
& =\frac{4752}{23520}=0.2020
\end{aligned}
$$

Since the number of criteria is greater $(m>7)$, thus the significance of the concordance coefficient is determined by using the $\chi^{2}$ criterion, to which the random variable is estimated by Equation 15:

\begin{tabular}{|c|c|c|c|c|c|c|c|}
\hline & \multirow{2}{*}{ Codes of experts } & \multicolumn{6}{|c|}{ Criteria for performance criteria are assessed by A group significances $(j=1,2, \ldots, 5)$} \\
\hline & & A1 & $\mathrm{A} 2$ & A3 & A4 & A5 & Overall sum \\
\hline \multirow{14}{*}{ 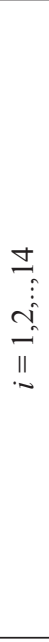 } & E1 & 1 & 4 & 3 & 5 & 2 & 15 \\
\hline & E2 & 3 & 1 & 2 & 4 & 5 & 15 \\
\hline & E3 & 3 & 2 & 4 & 5 & 1 & 15 \\
\hline & E4 & 1 & 3 & 4 & 5 & 2 & 15 \\
\hline & E5 & 4 & 5 & 1 & 3 & 2 & 15 \\
\hline & E6 & 2 & 1 & 4 & 3 & 5 & 15 \\
\hline & E7 & 4 & 1 & 3 & 5 & 2 & 15 \\
\hline & E8 & 2 & 1 & 4 & 3 & 5 & 15 \\
\hline & E9 & 2 & 1 & 4 & 3 & 5 & 15 \\
\hline & E10 & 2 & 3 & 1 & 5 & 4 & 15 \\
\hline & E11 & 1 & 5 & 3 & 4 & 2 & 15 \\
\hline & E12 & 4 & 3 & 5 & 1 & 2 & 15 \\
\hline & E13 & 1 & 2 & 4 & 5 & 3 & 15 \\
\hline & E14 & 1 & 2 & 4 & 5 & 3 & 15 \\
\hline & $\begin{array}{c}\text { Sum of the ranks } \\
R_{j}=\sum_{i=1}^{n} R_{i j}(j=1,2, \ldots, m)\end{array}$ & 31 & 34 & 46 & 56 & 43 & 210 \\
\hline & $\bar{R}=\frac{\sum_{j=1}^{\text {Average rank }} R_{i j}}{m}=\frac{\sum_{i=1}^{n} \sum_{j=1}^{m} R_{i j}}{m}$ & 2.21 & 2.43 & 3.29 & 4.0 & 3.07 & 15 \\
\hline & $\sum_{i=1}^{n} R_{i j}-\frac{1}{2} n(m+1)$ & -11 & -8 & 4.0 & 14 & 1 & 0 \\
\hline & {$\left[\sum_{i=1}^{n} R_{i j}-\frac{1}{2} n(m+1)\right]^{2}$} & 121 & 64 & 16 & 196 & 1 & 396 \\
\hline & Hierarchy & 1 & 2 & 4 & 5 & 3 & \\
\hline
\end{tabular}

$\chi^{2}=n \cdot(m-1) \cdot W=\frac{12 \cdot S}{n \cdot m \cdot(m+1)}=$

$=14 \cdot(5-1) \cdot 0.2020=\frac{12 \cdot 396}{14 \cdot 5 \cdot(5+1)}=11.3143$

Table 2 - Criteria evaluated according to the importance of group A (Technical properties of terminals) 
The lowest value of the concordance coefficient $W_{\min }$ is obtained:

$W_{\min }=\frac{\chi_{v, \alpha}^{2}}{n \cdot(m-1)}=\frac{9.48773}{14 \cdot(5-1)}=0.1694<0.2020$

The value is substantially lower than 0.202 . Thus, it is possible to claim that the judgements of all 14 experts are in agreement.

In the group of A criteria the experts defined the following sequence of the main factors characterising the technical qualities of terminals:

A1 (A1=2.21) - Railway infrastructure. This factor is expressed in terms of the number (units) and the length $(\mathrm{m})$ of railway trains at intermodal terminals. A2 (A2=2.43) - Road transport infrastructure. This factor is expressed in terms of production area $\left(\mathrm{m}^{2}\right)$ of road transport infrastructure in a terminal (the area designed for vehicle parking near terminal entrance and/or area for road transport servicing at the terminal).

A5 (A1=3.07) - Loading equipment. This factor is expressed in terms of the number of ITU maintenance equipment (units) for servicing intermodal transport units (refrigeration container handling equipment, equipment for the collection of hazardous cargo emergency consequences) and the production area (space of containers for partial repairs) $\left[\mathrm{m}^{2}\right]$.

A3 (A3=3.29) - Area of cargo storage. Expressed in terms of the total storage volume $\left[\mathrm{m}^{2}\right]$ of intermodal units (TEU and ro-ro cargo).
A4 (A4=4.0) - Technical equipment expressed by the number of equipment to service intermodal cargo as refrigerated cargo containers, equipment to eliminate accidents of hazardous cargo, and the area for containers servicing (repairing).

The weights of importance of the action group A (A1, A2, A3, A4, A5) criteria estimated according to Equation 17 are presented in Table 3, and the ranking by the importance of coefficients of criteria weights - in Figure 1.

$\omega_{1}=\frac{(m+1)-\bar{R}_{1}}{\sum_{j=1}^{5} \bar{R}_{j}}=\frac{(5+1)-2.21}{15}=0.253$

The sum of normalised A1, A2, A3, A4, A5 group factors equals 1 .

A vertical column diagram of the weight of importance of calculated values for all five Technical criteria is drawn in Figure 1.

As can be seen from Figure 1, the main factors of intermodal terminal technical parameters which have the greatest influence on the possibilities of transport synchromodality applications, are as follows: railway infrastructure (A1), road transport infrastructure (A2), and loading equipment (A5).

Factors of lesser importance: area of cargo storage (A3), and technical equipment (A4).

The following hierarchy is received of group factors affecting the transport synchronisation with weight coefficients:

$\mathrm{A} 1>\mathrm{A} 2>\mathrm{A} 5>\mathrm{A} 3>\mathrm{A} 4$

Table 3 - Weight of importance of group A (Technical qualities of terminals)

\begin{tabular}{||c|c|c|c|c|c|c||}
\hline \multirow{2}{*}{ Size } & \multicolumn{5}{|c|}{ Sign of action criteria } & \multirow{2}{*}{ Sum } \\
\cline { 2 - 7 } & $\mathrm{A} 1$ & $\mathrm{~A} 2$ & $\mathrm{~A} 3$ & $\mathrm{~A} 4$ & $\mathrm{~A} 5$ & 1 \\
\hline \hline$\omega_{j}$ & 0.253 & 0.238 & 0.181 & 0.133 & 0.195 & 1 \\
\hline Hierarchy & 1 & 2 & 4 & 5 & 3 & \\
\hline
\end{tabular}

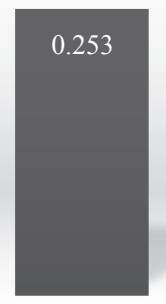

A1

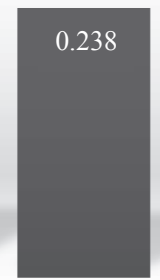

A2

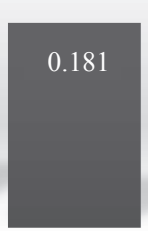

A3

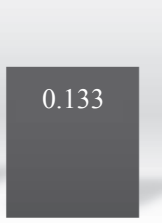

A4

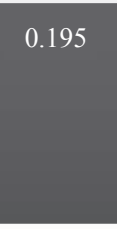

A5

Figure 1 - Breakdown of criteria weights by importance of Intermodal terminal technical criteria 
Technological interaction (criteria of group B) studies have been conducted similarly.

Table 4 indicates the calculations for rank averages of each criterion of group B. All calculations were made according to the formulas given above.

The concordance coefficient is calculated:

$$
\begin{aligned}
& W=\frac{12 \cdot S}{n^{2} \cdot\left(m^{3} \cdot m\right)}=\frac{12 \cdot S}{14^{2} \cdot\left(8^{3} \cdot 8\right)}=\frac{12 \cdot 2227}{196 \cdot 504}= \\
& =\frac{26724}{98784}=0.2705
\end{aligned}
$$

Since the number of criteria is greater $(m>7)$, thus the significance of the concordance coefficient is determined by using the $\chi^{2}$ criterion, to which the random variable is estimated by Equation 19:

$$
\begin{aligned}
& \chi^{2}=n \cdot(m-1) \cdot W=\frac{12 \cdot S}{n \cdot m \cdot(m+1)}= \\
& =14 \cdot(8-1) \cdot 0.2705=\frac{26724}{14 \cdot 8 \cdot(8+1)}=26.51
\end{aligned}
$$

The lowest value of the concordance coefficient $W_{\min }$ is obtained.

$W_{\min }=\frac{\chi_{v, \alpha}^{2}}{n \cdot(m-1)}=\frac{14.0671}{14 \cdot(8-1)}=0.1435<0.2705$
The value is substantially lower; thus, it is possible to claim that the judgements of all experts are in agreement.

In the group of $\mathrm{B}$ factors, the experts defined that the sequence of criteria by importance characterising interoperability of transport modes is as follows: B1 $(\mathrm{B} 1=2.5)-$ Seaports accessibility, expressed in $\mathrm{km}$.

B2 (B2=3.14) - Railway distribution stations accessibility, expressed in $\mathrm{km}$.

B4 (B4=3.57) - Logistics centres accessibility, expressed in $\mathrm{km}$.

B6 (B6=4.07) - Roads accessibility, expressed in $\mathrm{km}$.

B7 (B7=4.29) - Railways accessibility, expressed in $\mathrm{km}$.

B8 (B8=5.5) - Inland waterways accessibility, expressed in $\mathrm{km}$.

\begin{tabular}{|c|c|c|c|c|c|c|c|c|c|c|}
\hline & \multirow{2}{*}{ Codes of experts } & \multicolumn{9}{|c|}{ Criteria for performance criteria are assessed by B group significances $(j=1,2, \ldots, 8)$} \\
\hline & & $\mathrm{B} 1$ & $\mathrm{~B} 2$ & $\mathrm{~B} 3$ & $\mathrm{~B} 4$ & $\mathrm{~B} 5$ & B6 & $\mathrm{B} 7$ & $\mathrm{~B} 8$ & Overall sum \\
\hline \multirow{14}{*}{ 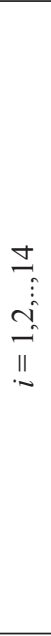 } & E1 & 3 & 2 & 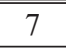 & 1 & 8 & 6 & 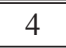 & 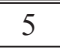 & 36 \\
\hline & E2 & 3 & 2 & 6 & 1 & 7 & 4 & 5 & 8 & 36 \\
\hline & E3 & 3 & 4 & 5 & 7 & 8 & 1 & 2 & 6 & 36 \\
\hline & E4 & 5 & 3 & 7 & 4 & 8 & 2 & 1 & 6 & 36 \\
\hline & E5 & 2 & 4 & 7 & 3 & 8 & 6 & 5 & 1 & 36 \\
\hline & E6 & 4 & 3 & 8 & 5 & 2 & 6 & 7 & 1 & 36 \\
\hline & E7 & 4 & 3 & 5 & 8 & 6 & 1 & 2 & 7 & 36 \\
\hline & E8 & 1 & 5 & 6 & 2 & 8 & 3 & 4 & 7 & 36 \\
\hline & E9 & 3 & 1 & 6 & 5 & 7 & 2 & 4 & 8 & 36 \\
\hline & E10 & 2 & 8 & 3 & 4 & 7 & 5 & 6 & 1 & 36 \\
\hline & E11 & 1 & 2 & 6 & 3 & 5 & 8 & 4 & 7 & 36 \\
\hline & E12 & 2 & 3 & 4 & 1 & 7 & 5 & 6 & 8 & 36 \\
\hline & E13 & 1 & 2 & 7 & 3 & 8 & 4 & 5 & 6 & 36 \\
\hline & E14 & 1 & 2 & 7 & 3 & 8 & 4 & 5 & 6 & 36 \\
\hline \multicolumn{2}{|c|}{$\begin{array}{c}\text { Sum of the ranks } \\
R_{j}=\sum_{i=1}^{n} R_{i j}(j=1,2, \ldots, m)\end{array}$} & 35 & 44 & 84 & 50 & 97 & 57 & 60 & 77 & 504 \\
\hline \multicolumn{2}{|c|}{$\bar{R}=\frac{\sum_{j=1}^{\text {Average rank }} R_{i j}}{n}(j=1,2, \ldots, m)$} & 2.5 & 3.14 & 6 & 3.57 & 6.93 & 4.07 & 4.29 & 5.5 & 36 \\
\hline \multicolumn{2}{|r|}{$\sum_{i=1}^{n} R_{i j}-\frac{1}{2} n(m+1)$} & -28 & -14 & 16 & -10 & 27 & -5 & -4 & 11 & 0 \\
\hline \multicolumn{2}{|r|}{$\left[\sum_{i=1}^{n} R_{i j}-\frac{1}{2} n(m+1)\right]^{2}$} & 784 & 196 & 256 & 100 & 729 & 25 & 16 & 121 & 2,227 \\
\hline \multicolumn{2}{|r|}{ Hierarchy } & 1 & 2 & 7 & 3 & 8 & 4 & 5 & 6 & \\
\hline
\end{tabular}

B3 (B3=6.0) - Airports accessibility, expressed in $\mathrm{km}$.

Table 4 - Criteria evaluated according to the importance of group $B$ 
Table 5 - Weight of importance of group B (Technological interaction)

\begin{tabular}{||c|c|c|c|c|c|c|c|c|c||}
\hline \multirow{2}{*}{ Size } & \multicolumn{8}{|c|}{ Sign of action criteria } & \multirow{2}{*}{ Sum } \\
\cline { 2 - 11 } & B1 & B2 & B3 & B4 & B5 & B6 & B7 & B8 & \\
\hline \hline$\omega_{j}$ & 0.181 & 0.163 & 0.083 & 0.151 & 0.057 & 0.137 & 0.131 & 0.097 & 1 \\
\hline Hierarchy & 1 & 2 & 7 & 3 & 8 & 4 & 5 & 6 & \\
\hline
\end{tabular}

Importance of B factors criteria

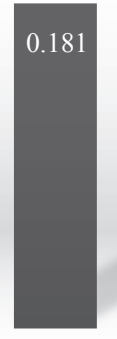

B1

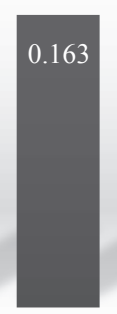

B2

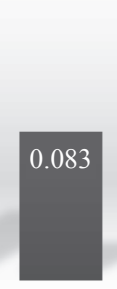

B3

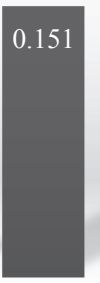

B4

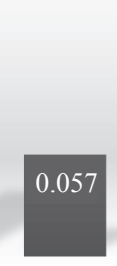

B5

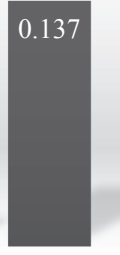

B6

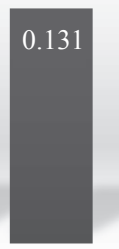

B7

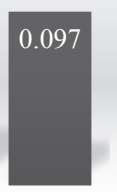

B8

Figure 2 - Breakdown of criteria weights by importance of Intermodal terminals technological criteria

B5 (B5=6.93) - Operational interaction of intermodal transport, loading carried out in order according to prior enquiries expressed as a percentage per month.

The weights of importance of action group $B$ (B1, B2, B3, B4, B5, B6, B7, B8) of criteria estimated according to Equation 8 are presented in Table 5, and ranking by the importance of coefficients of criteria weights - in Figure 2.

The sum of normalised B1, B2, B3, B4, B5, B6, $\mathrm{B} 7, \mathrm{~B} 8$ group criteria equals 1 .

A vertical column diagram of the average ranks of calculated values for all eight technological criteria is presented in Figure 2.

The following hierarchy is received of group factors affecting transport synchronisation with weight coefficients:

$\mathrm{B} 1>\mathrm{B} 2>\mathrm{B} 4>\mathrm{B} 6>\mathrm{B} 7>\mathrm{B} 8>\mathrm{B} 3>\mathrm{B} 5$

It is observed that the most influencing factors of technological interaction are: accessibility of seaports (B1), accessibility of railway distribution stations (B2), accessibility of logistics centres (B4), accessibility of roads (B6), and accessibility of railways (B7),

Factors of lesser importance: accessibility of inland waterways (B8), accessibility of airports (B3), and operational interaction of intermodal transport (B5).

The hypothesis that the synchronization of intermodal transport activities in international transport corridors depends on the technical characteristics of the terminals and technological interoperability was formulated. The formulated basic hypothesis can be confirmed. The research found that one of the most important technical factors of terminals is the railway and road transport infrastructure at the terminals and the loading equipment that have the greatest influence on the synchronization of transport activities. The technological interaction is mainly influenced by the connection with the seaports and railway distribution stations.

Synchronization of transport flows in the transport corridor is related to the improvement of the transport service level, capacities utilisation of transport hubs, and modal shift along the transport corridor.

In the following stages of the research, technical properties of terminals and technology interaction factors should be used to create an optimal model describing and facilitating synchronization with the aim of building an interconnected transport system spanning all modes of transport, where vehicle transport infrastructure continuously interacts, and the businesses are provided with easy and safe doorto-door mobility services.

\section{CONCLUSION}

The major technical and technological factors impacting synchronization of transport activities between intermodal nodes along the transport corridor have been researched and identified. 
According to experts the main factors of intermodal terminal technical parameters which have the greatest influence on the possibilities of transport synchronization applications, are as follows: railway infrastructure (A1), road transport infrastructure (A2), loading equipment (A5). Factors of lesser importance are: area of cargo storage (A3), technical equipment (A4).

It is observed that the most influencing factors of technological interaction are as follows: seaports accessibility (B1), railway distribution stations accessibility (B2), logistics centres accessibility (B4), roads accessibility (B6) as well as railway accessibility (B7). Factors of lesser importance are: inland waterways accessibility (B8), airports accessibility (B3) and operational interaction of intermodal transport (B5).

The main technical and technological factors (criteria) identified during the research as impacting synchronization of operational activity among transport hubs will help in further research to create models of synchronised activity in EWTC in the southern part of BSR and other international transport corridors. On the basis of synchronization it is possible to establish innovative transportation and logistics services through developing cooperation between intermodal terminals along a specific transport corridor.

\section{Dr. prof. NIJOLE் BATARLIENÉ}

El. paštas: nijole.batarliene@vgtu.lt

RAIMONDAS ŠAKALYS, doktorantas, tyrèjas ${ }^{1}$

El.paštas: raimondas.sakalys@vgtu.lt

${ }^{1}$ Vilniaus Gedimino technikos universitetas

Transporto inžinerijos fakultetas

Logistikos ir transporto vadybos katedra

Plytinès g. 27, LT-10105 Vilnius, Lietuva

\section{VEIKSNIAI, TURINTYS DIDŽIAUSIOS ITAKOS TRANSPORTO SRAUTU SINCHRONIZAVIMUI TARPTAUTINIAME TRANSPORTO KORIDORIUJE}

\section{SANTRAUKA}

Transporto srautu sinchronizavimas rytu-vakaru transporto koridoriuje (EWTC) pietineje Baltijos jūros regiono (BJR) dalyje yra susijęs su ịvairiarūšsio transporto terminaly techniniu ir technologiniu veiksniu suderinamumu ir su transporto paslaugu lygio gerinimu transporto koridoriuje. Pagrindinis šio straipsnio tikslas yra ištirti pagrindinius techninius ir technologinius veiksnius, kurie itakoja transporto srautu veiklos sinchronizavima EWTC koridoriuje, naudojant specialy klausimyna. Rezultatai buvo gauti naudojant Kendalo rangu koreliacijos metoda, o ekspertu atrankos suderinamumas buvo apskaičiuotas naudojant konkordancijos koeficienta. Pagal gautus skaičiavimus nustatyta, kad ekspertu nuomones yra suderintos. Tyrimo metu, naudojant vidutinio rango transformacijos $i$ svorius (ARTIW) metoda, buvo nustatyti normalizuoty subjektyviuju svoriu pagrindiniai techniniai ir technologiniai veiksniai, darantys didžiausia itaka transporto srautu sinchronizavimui. Terminaly techniniai ir technologiniai veiksniai apibūdina ịvairiarūšsio transporto terminalu pajegumus ir transporto rüšiu sqveikos efektyvumo panaudojimo galimybes. Straipsnyje pateikto tyrimo rezultatai parodè, kad pagrindiniai ịvairiarūšio transporto terminalu techniniai veiksniai, darantys itaka transporto srautu sinchronizavimui, yra šie: terminalu geležinkeliu infrastruktūra, keliu transporto infrastruktüra ir terminalu krovos ịrangos kiekis. Mažesnès svarbos veiksniai: kroviniu sandèliavimo plotas ir technines aptarnavimo irangos kiekis terminale. Taip pat buvo nustatyta, kad svarbiausi technologiniai veiksniai yra: susisiekimas su jūru uostais, susisiekimas su geležinkelio paskirstymo stotimis, su logistikos centrais bei su keliais, taip pat susisiekimas geležinkeliais. Mažiau svarbūs veiksniai: susisiekimas vidaus vandens transportu, susisiekimas su oro uostais ir jivairiarūšio transporto organizacine (operacinè) squeika. Tolesniuose tyrimo etapuose šios dvi veiksniu grupès turètu būti naudojamos kuriant sinchroninès veiklos modelius EWTC pietineje BJR dalyje ir kituose tarptautiniuose transporto koridoriuose. Remiantis sinchronizavimu, galima sukurti novatoriškas transporto ir logistikos paslaugas plètojant intermodaliniu terminaly veiklos bendradarbiavima konkrečiame transporto koridoriuje.

\section{RAKTINIAI ŽODŽIAI}

sinchronizavimas; techninis suderinamumas; technologine squeika; intermodalinis terminalas; transporto koridorius;

\section{REFERENCES}

[1] Behdani B, Fan Y, Wiegmans B, Zuidwijk R. Multimodal Schedule Design for Synchromodal Freight Transport Systems. European Journal of Transport and Infrastructure Research. 2016;(3): 424-444. Available from: doi:10.2139/ssrn.2438851 [Accessed 12 ${ }^{\text {th }}$ April 2019].

[2] Dong C, Boute R, McKinnon A, Verelst M. Investigating synchromodality from a supply chain perspective. Transportation Research Part D: Transport and Environment. 2018;61: 42-57. Available from: doi:10.1016/j. trd.2017.05.011 [Accessed 12 ${ }^{\text {th }}$ April 2019].

[3] Tavasszy LA, Behdani B, Konings R. Intermodality and Synchromodality. SSRN Electronic Journal. 2015;15. Available from: https://doi.org/10.2139/ssrn.2592888 [Accessed 12 $2^{\text {th }}$ July 2018].

[4] Buiel EFT, Visschedijk GC, Lebesque LHEM, Lucassen IMPJ, Riessen B, van Rijn A, van Brake GM. Synchro mania-design and evaluation of a serious game creating 
a mind shift in transport planning. $46^{\text {th }}$ International Simulation and Gaming Association Conference, ISAGA. 2015; p. 1-12. Available from: https://repository. tudelft.nl/view/tno/uuid:3c49819d-839e-4786-97dbc1ca02f606f3 [Accessed 22 $2^{\text {nd }}$ January 2019].

[5] Logistiek T, Partituur naar de top. Adviesrapport Topteam Logistiek. 2011. Available from: http://www.infrasite.nl/documents/bedrijven/1889/Adviesrapport $\% 20$ TopTeam\% 20Logistiek\%202011.pdf [Accessed 20 ${ }^{\text {th }}$ April 2019].

[6] Norman BA, Rajgopal J, Lim J, Gorham K, Haidari L, Brown ST, Lee BY. Modular vaccine packaging increases packing efficiency. Vaccine. 2015;33(27): 31353141. Available from: https://doi.org/10.1016/j.vaccine. 2015.04.091 [Accessed 12 ${ }^{\text {th }}$ April 2019].

[7] Defares D. Exploration of future container transport to and from the Dutch hinterland: Assessing the need for future policies. Master's thesis. Delft University of Technology; 2011. Available from: https://repository.tudelft.nl/islandora/object/uuid:a834577a-f4a34741-8185-267e51165566/ datastream/OBJ [Accessed $28^{\text {th }}$ April 2019].

[8] Ceder A, Golany B, Tal O. Creating bus timetables with maximal synchronization. Transportation Research Part A: Policy and Practice. 2001;35(10): 913-928. Available from: https://doi.org/10.1016/S0965-8564(00)00032-X [Accessed 12 ${ }^{\text {th }}$ April 2019].

[9] Šakalys R, Sivilevičius H, Miliauskaitè L, Šakalys A. Investigation and evaluation of main criteria impacting synchromodality using ARTIW and AHP methods. Transport. 2019;34(3): 300-311.

[10] Šakalys R, Batarlienė N. Research on intermodal terminal interaction in international transport corridors. Procedia Engineering. 2017;187: 281-288. Available from: doi:10.1016/j.proeng.2017.04.376 [Accessed 12 ${ }^{\text {th }}$ April 2018].

[11] Rodrigue JP. Globalization and the synchronization of transport terminal, Journal of Transport Geography. 1999;(7): 255-261.

[12] Rodrigue JP, Notteboom T. Foreland-based regionalization: Integrating intermediate hubs with port hinterlands. Research in Transport Economics. 2010;27(1): 19-29.

[13] Wilmsmeier G, Monios J, Lambert B. The directional development of intermodal freight corridors in relation to inland terminals. Journal of Transport Geography. 2011;(19): 1379-1386.

[14] Limbourg S, Jourquin B. Optimal rail-road container terminal locations on the European network. Transportation Research Part E. 2009;(45): 551-563.

[15] Vinke PJ. Dynamic consolidation decisions in a synchromodal environment: Improving the synchromodal control tower. Master's thesis. University of Twente; 2016. Available from: https://essay.utwente.nl/69109/1/Vinke_MA_BMS.pdf [Accessed $12^{\text {th }}$ April 2019].

[16] Kos S, Vukić L, Brčić D. Comparison of External Costs in Multimodal Container Transport Chain. Promet Traffic\&Transportation. 2017;29(2): 243-252. Available from: doi:10.7307/ptt.v29i2.2183 [Accessed 22 ${ }^{\text {nd }}$ May 2019].

[17] Pomponi F, Fratocchi L, Tafuri RS. Trust Development and Horizontal Collaboration in Logistics: A Theory Based Evolutionary Framework. Supply Chain
Management. 2015;20(1): 83-97. Available from: https:// doi.org/10.1108/SCM-022014-0078 [Accessed 10 ${ }^{\text {th }}$ January 2019].

[18] Veenstra A, Zuidwijk R, Van Asperen E. The extended gate concept for container terminals: Expanding the notion of dry ports. Maritime Economics \& Logistics. 2012;14(1): 14-32. Available from: https://doi. org/10.1057/mel.2011.15 [Accessed $10^{\text {th }}$ January 2019].

[19] Bontekoning YM, Macharis C, Trip JJ. Is a New Applied Transportation Research Field Emerging? Review of Intermodal Rail-Truck Freight Transport Literature. Transportation Research Part A: Policy and Practice. 2004;38(1): 1-34. Available from: doi:10.1016/j. tra.2003.06.001 [Accessed 22 ${ }^{\text {th }}$ April 2018].

[20] Brümmerstedt K, Beek MV, Münsterberg T. Comparative analysis of synchromodality in major European seaports. Proceedings of the Hamburg International Conference of Logistics (HICL-24), Nov 2017, Hamburg, Germany; 2017. p. 59-76. Available from: doi: $10.15480 / 882.1477$ [Accessed 22 ${ }^{\text {th }}$ April 2018].

[21] via donau - Österreichische Wasserstraßen. Manual on Danube navigation. Vienna; 2013. 218 p. Available from: http://inesdanube.info/goto.php?target=file_1545_download\&client_id=viailias4 [Accessed $22^{\text {nd }}$ April 2018].

[22] Alessandri A, Sacone S, Siri S. Modelling and optimal receding-horizon control of maritime container terminals. Journal of Mathematical Modelling and Algorithms. 2007;6(1): 109-33. Available from: https://doi. org/10.1007/s10852-006-9052-3 [Accessed 29 $9^{\text {th }}$ April 2019].

[23] Nabais JL, Negenborn RR, Botto MA. Hierarchical model predictive control for optimizing intermodal container terminal operations. Proceedings of the $16^{\text {th }}$ International IEEE Conference on Intelligent Transportation Systems (ITSC 2013). The Hague, Netherlands; 2013. Available from: doi:10.1109/ITSC.2013.6728314 [Accessed $12^{\text {th }}$ April 2019].

[24] Jarašūnienė A, Greičiūnė L, Šakalys A. Research of competitive environment of Klaipeda Seaport comparing to other seaports in the eastern Baltic Sea region. Transport. 2012;27(1): 5-13. Available from: doi:10.3846/1648414 2.2012.662911 [Accessed 22 ${ }^{\text {nd }}$ April 2019].

[25] TENTacle project 2019. Available from: http://www.tentacle.eu/a/uploads/dokument/TENTacle_report_final.pdf [Accessed 10 ${ }^{\text {th }}$ March 2019].

[26] Kendall M. Rank correlation methods. $4^{\text {th }}$ edition. London: Griffin and Co; 1970.

[27] Kendall M, Gibbons JD. Rank correlation methods. Fifth edition. London; 1990.

[28] Montgomery DC. Statistical Quality Control: A Modern Introduction. $7^{\text {th }}$ edition. Arizona: John Willey and Sons. Inc.; 2013.

[29] Sivilevičius H, Maskeliūnaitè L. Multiple Criteria Evaluation and the Inverse Hierarchy Model for Justifying the Choice of Rail Transport Mode. Promet - Traffic\&Transportation. 2018;30(1): 57-69. Available from: doi:10.7307/ptt.v30i1.2417 [Accessed 10 ${ }^{\text {th }}$ March 2019]. 